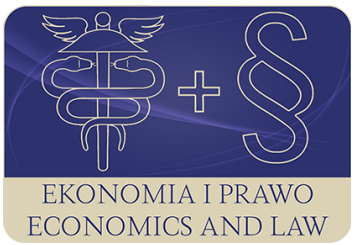

EKONOMIA I PRAWO. ECONOMICS AND LAW

Volume 18, Issue 3, September 2019

p-ISSN 1898-2255, e-ISSN 2392-1625

www.economicsandlaw.pl

ORIGINAL ARTICLE

received 15.07.2018; revised 12.07.2019; accepted 30.09.2019

Citation: Sosnowski, T. \& Wawryszuk-Misztal, A. (2019). Diversity on management and supervisory board and accuracy of management earnings forecasts in IPO prospectuses. Ekonomia i Prawo. Economics and Law, 18(3): 347-363. doi:10.12775/EiP.2019.024.

\title{
Diversity on management and supervisory board and accuracy of management earnings forecasts in IPO prospectuses
}

\section{TOMASZ SOSNOWSKI}

corresponding author

University of Lodz, Faculty of Economics and Sociology, Department of International Investments and Finance, ul. Rewolucji 1905 r. 41, 90 -214 Lodz, Poland

$\square$ tomasz.sosnowski@uni.lodz.pl

(D) orcid.org/0000-0001-5610-0404

\section{ANNA WAWRYSZUK-MISZTAL}

Maria Curie-Sklodowska University in Lublin, Faculty of Economics, Department of Corporate

Finance, Poland

๑anna.wawryszuk@umcs.pl

(iD) orcid.org/0000-0002-5016-9117

\begin{abstract}
Motivation: Although the issue of accuracy and bias of earnings forecasts revealed in the IPO prospectuses has attracted attention of many researchers, the literature on the relationship between board characteristics and the quality of such financial projections is still very limited, especially for a two-tier board structure consisting of the management and the supervisory board. The policy of diversity on the boardroom is promoted in many countries and composition of the management and supervisory boards is expected to be comprehensive and diverse, among others, in terms of gender, education, age and professional experience of the members.

Aim: The main objective of this study is to analyse the relationship between the accuracy of the earnings forecast disclosed in the IPO prospectus and the diversity of company's corporate governance institutions. More specifically, we ask a question whether the extent
\end{abstract}


of diversity in the board system features may have an impact on the accuracy of such forward-looking financial information.

Results: Using a sample of 104 IPOs from the Warsaw Stock Exchange, we find that certain characteristics of the management and supervisory board enhance the usefulness of forward-looking financial information from a IPO prospectus, as some of boards characteristics are important for the evaluation of the earnings forecasts credibility at the time

of IPO. For example, in accordance with our expectations, the age diversity results in more accurate forecasts. This evidence may be seen as an argument for diversity policy among board members.

Keywords: corporate governance; IPO forecast accuracy; management and supervisory board diversity; forecast error JEL: G17; G23; G34

\section{Introduction}

The issue of diversity is a hot topic present in popular press and in policy discussions (Filbeck et al., 2017), therefore it attracts attention of academic researchers. The term diversity may be defined as 'policies and practices that seek to include people who are considered, in some way, different from traditional members' (Herring, 2009, p. 209). The diversity may refer to different kinds of groups, but especially it attracts attention of academics who analyse the results of diversity in workplace. They usually assume that diversity in workforce increases productivity, creative thinking and financial results of companies (Backes-Gellner \& Veen, 2013).

The board of directors is a group of people, which plays the crucial role in the company - it monitors the behaviour of managers, provides valuable resources, gives strategic advice, enhances the company's reputation, and expands the company's network of business contacts (Bertoni et al., 2014, p. 1). To perform its duties and responsibilities more effectively, the balanced board membership is required (Toumi et al., 2016). Heterogeneous boards are expected to be more innovative and creative in a problem-solving or decision-making process and better at understanding the business than homogeneous ones (Mishra \& Jhunjhunwala, 2013, pp. 5-7).

The expected positive outcomes of board diversity are usually explained by the resource dependency theory and the human capital theory. According to the dependency theory firms depend on their environment (Pfeffer, 1972), and more specifically, on the ability of acquiring resources from the environment. In case of a more diverse board access to key resources, such as information and networks, is better than for less diverse one (Bryant \& Davis, 2012, p. 6). The human capital theory assumes that such characteristics of human capital as knowledge and skills of board members are crucial in carrying out the monitoring and resources provision roles (Hillman \& Dalziel, 2003). As the boards diversity provides the company with different knowledge and skills, it enables 
to create unique human capital and thus to increase the company's performance (Carter et al., 2010).

While many existing studies tries to find the link between the board diversity and performance (Hassan et al., 2015; Mahadeo et al., 2012; Taljaard et al., 2015), the quality of financial reporting (Al-Shaer \& Zaman, 2016) or willingness to disclose financial projections (Kilic \& Kuzey, 2018), we analyse the relationship between the accuracy of the earnings forecast voluntary disclosed in the IPO prospectus and the diversity of company's corporate governance system. More specifically, we examine the effect of pre-IPO management and supervisory board diversity in terms of gender, age, educational background on the accuracy of management earnings forecast in companies going public and we ask the question whether the extent of diversity in the board system may have an impact on the accuracy of such forward-looking financial information.

Disclosure of financial forecasts in IPO prospectuses reduces the information asymmetry between managers and investors which may result in better investment decisions and successful listing (Chong \& Ho, 2007, p. 63; Jog \& McConomy, 2003). Nevertheless, the usefulness of such projections depends on their accuracy. As the previous literature on earnings forecasts accuracy provide evidence that earnings forecasts are usually inaccurate, some researchers examine determinants of the accuracy (Ahmad-Zaluki \& Wan-Hussin, 2010; Lonkani \& Firth, 2005). The findings of previous research show that some of the corporate governance attributes may be important factors affecting profit projections accuracy, nevertheless the results of this studies are mixed (Ammer \& Ahmad-Zaluki, 2014, 2017; Bédard et al., 2008).

In this study we apply a set of variables as proxies of board diversity to analyse the relationship between the board composition and the accuracy of earnings forecasts. We hypothesize that inclusion in the management and supervisory board members that are varied in terms of gender, age, type and a level of education, has positive an impact on the quality of forecasts disclosed in the prospectus.

The motivation to conduct our research is derived from two reasons. First, the policy of diversity on the boardroom is promoted in many countries by implementing adequate regulations applying to the board composition and it is also often present in codes of bests practices voluntarily adopted by public companies. As this actions are based on the assumption that diversity results in positive outcomes, especially in the area of the company's performance, the issue of diversity attracts attention of researchers. Second, the literature on the relationship between board characteristics and the quality of such financial projections is still very limited, especially for a two-tier board structure consisting of the management and the supervisory board.

\section{Literature review}

The literature referring to the topic of board diversity and its impact on the company is very extensive, but empirical studies on association between board het- 
erogeneity and earnings forecasts revealed by mangers are very limited. The board diversity means the presence of members that differ with respect to some attributes, both observable as gender, age, ethnical background and less visible features like 'educational, functional and occupational backgrounds, industry experience, and organizational membership' (Kang et al., 2007, p. 195).

Among the mentioned characteristics, gender is probably the most extensively studied one. In terms of gender the diversity means the equal proportion of females to males in the boardroom. The literature emphasizes that women differ from men in terms of leadership style, priorities, the way of problem solving (Al-Shaer \& Zaman, 2016, p. 212; Bohdanowicz, 2011, p. 182). They are perceived as being more stakeholder oriented or likely to realize responsible actions (Al-Shaer \& Zaman, 2016, p. 212). Due to the above factors explaining a unique role of women in the company, one would expect positive results of women's presence in the board, and thus their positive impact on the accuracy of earnings forecasts.

Although the presence of women in corporate boards is analysed as factor determining the company's performance (Bennouri et al., 2018), earnings management (Huang et al., 2012), reporting quality (Al-Shaer \& Zaman, 2016), willingness to voluntarily disclose information (Ahmed et al., 2017) or risk undertaken by the company (Huang \& Kisgen, 2013), research on the role of women in preparing accurate forecasts has not attracted many attention of researchers. Ammer \& Ahmad-Zaluki (2017) studied the association between gender diversity in audit committees in Malaysian companies and accuracy of management earnings forecasts, but contrary to the expectations, they document the negative association between these variables. They explain this result by a very small representation of women in corporate boards.

Age is another dimension of board diversity. It means the equal proportion of young, middle- and senior-aged directors (Mishra \& Jhunjhunwala, 2013, p. 75). Positive outcomes of board members at different age, especially young individuals stem from the fact, that company needs young people, who better than older members catch up with rapid changes in technology and social trends (Mishra \& Jhunjhunwala, 2013, p. 75). Young people bring to the company vitality, energy, willingness to take up risky projects and generally readiness to challenges (Houle 1990, p. 34; Mishra \& Jhunjhunwala, 2013, pp. 7576). Nevertheless, senior managers are perceived as being more experienced and skilled. As they possess strong personal networks, they facilitate the board to perform its important function, i.e. 'to aquire resources and develop relationships with external agencies' (Mishra \& Jhunjhunwala, 2013, p. 76). Thus, it is expected, that board diversity in respect to age results in better company outcomes. Yet, some of the research provides arguments against the boards diversity, documenting negative association between the company's performance and age diversity (Abdullah \& Ku Ismail, 2013; Talavera et al., 2018, p. 60).

Relatively a less studied dimension of board diversity is educational background. Educational heterogeneity means appointing to the board members 
from different professional fields. The literature argues that educational diversity on the board leads to more comprehensive problem solving and makes the team more innovative (Jhunjhunwala \& Mishra, 2012, p. 71). Some of the researchers examine the impact of educational background diversity on the company's performance (Camelo et al., 2010; Eulerich et al., 2014; Mahadeo et al., 2012), but they usually find the negative association between performance and educational diversity.

The above examples of studies on boards diversity lead us to conclusion, that this issue is still important and requires in-depth research.

\section{Methods}

Our initial sample consists of all 337 IPOs listed on the Warsaw Stock Exchange from 2006 to 2016. The sample period starts from 2006 because in that year all WSE-issuers started applying the new legal regulations concerning the IPO, including the content of the prospectus and voluntary disclosure of the forward-looking financial reporting in the going public process (Act on Public Offering, 2005). Then, we exclude IPOs without the sale of primary or secondary shares, companies previously listed on alternative public trading systems (e.g. NewConnect), foreign companies, banks and insurance companies. After using those filters we hand-collected prospectuses of all the remaining companies and identified our final sample. This screening procedure yields a final sample of 104 IPOs over the 2006-2016 period that reveled to the public the earnings forecast for the IPO year in the IPO prospectus.

Table 1 presents a detailed definition of all the variables used in the study. We use two sets of dependent variables in the empirical analysis to investigate the forecasting quality in the IPO prospectus. The first set includes the relative (FER) and absolute (AFER) measure of forecast error commonly used in literature (Lonkani \& Firth, 2005). Then, as we do not expect the forward-looking financial projections presented in the IPO prospectus to be entirely accurate (i.e. $A F E R=0$ ), we employ the second set of dummy variables regarding the accuracy and bias of the earnings forecasts, namely accurate, optimistic, pessimistic. Our approach to the $10 \%$ threshold of the forecast accuracy is in line with the Polish legal regulations, i.e. it is obligatory to publish information in the form of a current report on a possible revision of the forecast provided in the IPO prospectus if the projected data are expected to differ by at least $10 \%$ compared to its last value published to the public (Regulation on current and periodic information provided by issuers of securities, 2005, paragraph 31). Taking into account the nature of the explanatory variables, we use OLS and Logit regressions in this study, respectively.

Next, we use two types of independent variables in separate equations for the management and supervisory board. The first group denotes the diversity of the board composition. To investigate the variety of management and su- 
pervisory board in $i$ company, we employ the Blau's index, which is given by the following formula:

$$
\text { Blau's index }=1-\left[\sum_{g=1}^{n}\left(\frac{\text { members }_{g}}{\text { boards size }}\right)^{2}\right]_{i},
$$

where memebrs is the number of board members in each cohort $(\mathrm{g})$. The lower value the Blau's index takes the more homogeneous in terms of characteristics of our main interest the individuals are (Solanas et al., 2012). As we analyze the diversity of the management and supervisory board composition from the point of view of age (age), gender (gender), as well as type (edu_type) and level (edu_lev) of education, we calculate separate indices for each of these features classifying all board members into distinct cohorts (see table 2). We add also size, as larger boards are expected to be more diverse in general. The second group of variables consists of three control variables suggested by the literature to be important in explaining the earnings forecast accuracy disclosed in IPO prospectuses. Because we suppose the difference in board ownership may contribute to the reliability of managerial earnings forecast, we employ ownership. Moreover, as a long-term financial prediction is more difficult and the probability of making the forecast error rises, we use horizon. Then we employ assets as more mature and larger issuers are considered to have greater forecasting precision.

All the data concerning the characteristics of the analyzed companies, board and earnings forecast have been hand-collected from the IPO prospectuses. We retrieved the financial information on the real net earnings from the financial statements available in the Notoria Service database.

\section{Results}

Table 3 shows the descriptive statistics for the variables applied in our research. It reveals that the reported earnings differ from their projected value on average at $34.05 \%$, hence one can conclude that generally the IPO prospectus forecasts are not accurate. What is more, such predictions are optimistically biased since the mean value of FER is at $-16.21 \%$.

Comparing the mean values of all independent variables used as proxies for board diversity one would notice that on average supervisory boards are more heterogeneous than management boards. Charts 1 and 2 show that among members of management boards the largest group of people have technical education, while members of the supervisory board usually hold economic education. A higher level of education is the most frequent characteristic, both for management and supervisory board members. Moreover, members with doctor's and professor's degrees are more likely to be appointed to supervisory boards than to management boards. The results for another diversity di- 
mension - age - show the higher participation of older (more than 55 years) and younger members (less than 35 years) in supervisory boards than in management boards. The low presence of women in management and supervisory boards explains the relatively low level of board diversity in terms of gender.

To identify and avoid the risk of multicollinearity in our research before the regression analysis, we check the pairwise correlation among the independent variables. Table 4 shows the Pearson correlation coefficient, separately both for management and supervisory board. As far as no significant threshold has been exceeded for statistically significant coefficients, this issue does not seem to be a problem in our study.

The results of multiple regression analysis (OLS) are presented in tables 5 and $6-$ the columns named FER and AFER. The diversity of management and supervisory board in terms of age is associated with the higher quality of earnings projections. The appointment of members of different ages to management or supervisory boards reduces AFER, which means that earnings forecasts are more accurate. Nevertheless, a positive coefficient for FER and age variables leads to the conclusion that more heterogeneous boards in terms of age are likely to disclose more pessimistic forecasts. However, contrary to our expectation, the quality of earnings projections decreases as the management board is more diverse in terms of gender. The presence of women seems to have a negative impact on forecasts accuracy and results in more optimistic forecasts. Surprisingly, similar results are not observed for supervisory boards, where women's membership is more visible than in management boards. The obtained results show the importance of size and horizon variables in explaining the earnings forecasts accuracy.

The last three columns (accurate, opimistic, pessimistic) in tables 5 and 6 report the results of the logistic regression analysis. These results confirm some of the findings stemming from the multiple regression analysis. The presence of members of different ages in the management board decreases the probability of disclosing optimistic projections and increases the probability of issuing pessimistic forecasts. More accurate projections are likely to be published as the supervisory board diversity in terms of age is higher. Similarly, appointing to the supervisory board members that differ in terms of age reduces the probability of optimistic earnings forecast disclosure. More accurate forecasts are likely to be published as the management board diversity in terms of gender decreases. What is more, female representation in management boards leads to more optimistic forecasts, as it was pointed above. However, the presence of women in the supervisory board increases the accuracy of earnings forecasts. Referring to education as a dimension of boards diversity, one would notice the importance of education type for earnings accuracy in case of the supervisory board. A more diverse supervisory board in terms of education discipline results in inaccurate and optimistic forecasts. The results of the logistic regression also document that a higher proportion of shares owned by manage- 
ment board members results in more optimistic and less pessimistic earnings forecasts.

\section{Conclusion}

The diversity policy is a topic of many interests, but some of the aspects of this issue have not been extensively studied so far. We examined the relation between boards diversity and the quality of earnings forecasts voluntarily disclosed in prospectuses by Polish IPO companies. Relying on the resource dependency theory and human capital theory, we expected that a higher level of management and supervisory boards diversity in terms of education type and level, age, as well as gender will result in higher accuracy of profit projections revealed in the prospectus.

Our findings lead us to accept our hypothesis in part. The results provide arguments for appointing to management and supervisory boards members of different ages. Nevertheless, contrary to our expectation the women's presence in management board has a negative impact on forecasts accuracy and is not relevant in case of the supervisory board. What is more, our results do not provide support for educational diversity in boards. On this basis we may suppose, that former experience is more important than formal education.

As the credibility of financial information disclosed in the IPO prospectus is associated with some of the boards characteristics, the findings of this research may be used by investors who intend to purchase IPO shares.

\section{References}

Abdullah, S.N., \& Ku Ismail, K.N.I. (2013). Gender, ethnic and age diversity of the boards of large malaysian firms and performance. Jurnal Pengurusan, 38. doi:10.17576/pengurusan-2013-38-03.

Ahmad-Zaluki, N.A., \& Wan-Hussin, W.N. (2010). Corporate governance and earnings forecasts accuracy. Asian Review of Accounting, 18(1). doi:10.1108/13217341011046006.

Ahmed, A., Monem R.M., Delaney, D., \& Ng, C. (2017). Gender diversity in corporate boards and continuous disclosure: Evidence from Australia. Journal of Contemporary Accounting \& Economics, 13(2). doi:10.1016/j. jcae.2017.05.004.

Al-Shaer, H., \& Zaman, M. (2016). Board gender diversity and sustainability reporting quality. Journal of Contemporary Accounting \& Economics, 12(3). doi:10.1016/j.jcae.2016.09.001.

Ammer, M.A., \& Ahmad-Zaluki, N.A. (2014). Absolute forecast errors of earnings in malaysian IPO prospectuses: the impact of ethnic diversity. Jurnal Teknologi, 68(3). doi:10.11113/jt.v68.2954. 
Ammer, M.A., \& Ahmad-Zaluki, N.A. (2017). The role of the gender diversity of audit committees in modelling the quality of management earnings forecasts of initial public offers in Malaysia. Gender in Management: An International Journal, 32(6). doi:10.1108/GM-09-2016-0157.

Backes-Gellner, U., \& Veen, S. (2013). Positive effects of ageing and age diversity in innovative companies: large scale empirical evidence on company productivity. Human Resource Management Journal, 23(3). doi:10.1111/1748-8583.12011.

Bédard, J., Coulombe, D., \& Courteau, L. (2008). Audit committee, underpricing of IPOs, and accuracy of management earnings forecasts. Corporate Governance: An International Review, 16(6). doi:10.1111/j.1467-8683.2008.00708.x.

Bennouri, M., Chtioui, T., Nagati, H,. \& Nekhili, M. (2018). Female board directorship and firm performance: what really matters? Journal of Banking and Finance, 88. doi:10.1016/j.jbankfin.2017.12.010.

Bertoni, F., Meoli, M., \& Vismara, S. (2014). Board independence, ownership structure and the valuation of IPOs in continental Europe. Corporate Governance: An International Review, 22(2). doi:10.1111/corg.12051.

Bohdanowicz, L. (2011). Kobiety w radach nadzorczych i zarządach spółek: polskie i światowe tendencje oraz wyzwania. Organizacja i Kierowanie, 3(146).

Bryant, P., \& Davis, C. (2012). Regulated change effects on boards of directors: a look at agency theory and resource dependency theory. Academy of Strategic Management Journal, 11(2).

Camelo, C., Fernández-Alles, M., \& Hernández, A.B. (2010). Strategic consensus, top management teams, and innovation performance. International Journal of Manpower, 31(6). doi:10.1108/01437721011073373.

Carter, D.A., D'Souza, F., Simkins, B.J., \& Simpson, W.G. (2010). The gender and ethnic diversity of US boards and board committees and firm financial performance. Corporate Governance: An International Review, 18(5). doi:10.1111/j.1467-8683.2010.00809.x.

Chong, B.S, \& Ho, K.W. (2007). Lockup and voluntary earnings forecast disclosure in IPOs. Financial Management, 36(3). doi:10.1111/j.1755-053X.2007. tb00081.x.

Eulerich, M, Velte, P., \& Van Uum, C. (2014). The impact of management board diversity on corporate performance: an empirical analysis for the German two-tier system. Problems and Perspectives in Management, 12(1).

Filbeck, G., Foster, B., Preece, D., \& Zhao, X. (2017). Does diversity improve profits and shareholder returns? Evidence from top rated companies for diversity by DiversityInc. Advances in Accounting, 37. doi:10.1016/j. adiac.2017.02.001.

Hassan, R., Marimuthu, M., \& Johl, S.K. (2015). Diversity, corporate governance and implication on firm financial performance. Global Business and Management Research: An International Journal, 7(2). 
Herring, C. (2009). Does diversity pay? Race, gender, and the business case for diversity. American Sociological Review, 74(2). doi:10.1177/000312240907400203.

Hillman, A.J., \& Dalziel, T. (2003). Board of directors and firm performance: integrating agency and resource dependence perspectives. Academy of Management Review, 28(3). doi:10.2307/30040728.

Houle, C.O. (1990). Who should be on your board? Nonprofit World, 8(1).

Huang, H.H., Chan, M.L., Chang, C.H., \&Wong, J.L. (2012). Is corporate governance related to the conservatism in management earnings forecasts? Emerging Markets Finance \& Trade, 48(S2), doi:10.2753/ REE1540-496X48S206.

Huang, J., \& Kisgen, D. (2013). Gender and corporate finance: are male executives overconfident relative to female executives? Journal of Financial Economics, 108(3). doi:10.1016/j.jfineco.2012.12.005.

Jhunjhunwala, S., \& Mishra, R.K. (2012). Board diversity and corporate performance: the Indian evidence. The IUP Journal of Corporate Governance, 11(3).

Jog, V.J., \& McConomy, R.J. (2003). Voluntary disclosure of management earnings forecasts in IPO prospectuses. Journal Business Finance \& Accounting, 30(1-2). doi:10.1111/1468-5957.00486.

Kang, H., Cheng, M., \& Gray, S.J. (2007). Corporate governance and board composition: diversity and independence of Australian boards. Corporate Governance: An International Review, 15(2). doi:10.1111/j.1467-8683.2007.00554.x.

Kilic, M., Kuzey, C., (2018). Determinants of forward-looking disclosures in integrated reporting. Managerial Auditing Journal, 33(1). doi:10.1108/ MAJ-12-2016-1498.

Lonkani, R., \& Firth, M. (2005). The accuracy of IPO profit forecasts in Thailand and their relationships with stock market valuation. Accounting and Business Research, 35(3). doi:10.1080/00014788.2005.9729991.

Mahadeo, J.D., Soobaroyen, T., \& Oogarah-Hanuman, V. (2012). Board composition and financial performance: uncovering the effects of diversity in an emerging economy. Journal of Business Ethics, 105(3). doi:10.1007/ s10551-011-0973-z.

Mishra, R.K., \& Jhunjhunwala, S. (2013). Diversity and the effective corporate board. Oxford: Elsevier. doi:10.1016/c2012-0-06237-0.

Pfeffer, J. (1972). Size and composition of corporate boards of directors: the organization and its environment. Administrative Science Quarterly, 17(2). doi:10.2307/2393956.

Rozporządzenie Ministra Finansów z dnia 19 października 2005 w sprawie informacji bieżących i okresowych przekazywanych przez emitentów papierów wartościowych [Regulation of the Minister of Finance of 19 October 2005 on current and periodic information provided by issuers of securities] (Dz.U. 2005 nr 209 poz. 1744) (Poland). 
Solanas, A., Selvan, R.M., Navarro, J., \& Leiva, D. (2012). Some common indexes of group diversity: upper boundaries. Psychological Reports, 111(3). doi:10.2466/01.09.21.pr0.111.6.777-796.

Talavera, O., Yin, S. \& Zhang, M. (2018). Age diversity, directors' personal values, and bank performance. International Review of Financial Analysis, 55. doi:10.1016/j.irfa.2017.10.007.

Taljaard, C.CH; Ward, M. JD, \& Muller, C.J. (2015). Board diversity and financial performance: a graphical time-series approach. South African Journal of Economic and Management Sciences, 18(3). doi:10.4102/sajems.v18i3.926.

Toumi, N., Benkraiem, R., \& Hamrouni, A. (2016). Board director disciplinary and cognitive influence on corporate value creation. Corporate Governance: The International Journal of Business in Society, 16(3). doi:10.1108/ CG-09-2015-0123.

Ustawa z dnia 29 lipca 2005 r. o ofercie publicznej i warunkach wprowadzania instrumentów finansowych do zorganizowanego systemu obrotu oraz o spółkach publicznych [Act of 29 July 2005 on public offering, conditions governing the introduction of financial instruments to organised trading, and public companies] (Dz.U. 2005 nr 184 poz. 1539) (Poland).

\section{Acknowledgements}

Author contributions: authors have given an approval to the final version of the article. Authors contributed to this work equally.

Funding: this research was funded by the University of Lodz, Faculty of Economics and Sociology statutory sources.

Supplementary information: authors acknowledge following people and institution for help with the preparation of the article: participants of the Second Scientific Conference Institutions: theory and practice (June, 19-20 2018, Torun, Poland) at the University of Nicolaus Copernicus in Torun for helpful comments and suggestions. All mistakes remain ours.

Note: the results of this study were presented at Second Scientific Conference Institutions: theory and practice (June, 19-20 2018, Torun, Poland). 


\section{Appendix}

Table 1.

\section{Variable description}

\begin{tabular}{|c|c|}
\hline Variable & Definition \\
\hline \multicolumn{2}{|r|}{ Panel A: depend variables } \\
\hline FER & $\begin{array}{l}\text { Earnings forecast error equals the difference between the earnings realized in the IPO year and its } \\
\text { predicted value as given in the prospectus scaled to the absolute value of the earnings forecasts. }\end{array}$ \\
\hline AFER & Absolute earnings forecast error calculated as the absolute value of FER. \\
\hline accurate & $\begin{array}{l}\text { Dummy variable, which equals one if the actual net profit did not differ by more than }+/-10 \% \text { from } \\
\text { the forecasted value and zero otherwise. }\end{array}$ \\
\hline optimistic & Dummy variable, which equals one if the value of FER is less than $-10 \%$ and zero otherwise. \\
\hline pessimistic & Dummy variable, which equals one if the value of FER is more than $+10 \%$ and zero otherwise. \\
\hline \multicolumn{2}{|r|}{ Panel B: independ variables } \\
\hline edu_type & The value of Blau's index measuring the diversity in type of education among board members. \\
\hline edu_lev & The value of Blau's index measuring the diversity in level of education among board members. \\
\hline age & The value of Blau's index measuring the diversity in age among board members. \\
\hline gender & The value of Blau's index measuring the diversity in gender among board members. \\
\hline size & The number of members in the management or supervisory board of IPO firm, respectively. \\
\hline ownership & $\begin{array}{l}\text { The ratio of the total number of shares held by all directors (supervisors) to the total number of pre- } \\
\text { IPO outstanding shares. }\end{array}$ \\
\hline horizon & $\begin{array}{l}\text { The natural logarithm of the number of days from the release of the prospectus to the end of the IPO } \\
\text { year. }\end{array}$ \\
\hline assets & The natural logarithm of the total assets at the end of the year prior to the IPO. \\
\hline
\end{tabular}

Source: Authors' own preparation.

Table 2.

Definition of cohort used in Blau's index calculation

\begin{tabular}{|c|c|}
\hline Cohort specification & Cohort description \\
\hline edu_type & $\begin{array}{l}\text { The type of education the board members have, divided into four groups: economic educa- } \\
\text { tion, technical education, legal education and other type of education. }\end{array}$ \\
\hline edu_lev & $\begin{array}{l}\text { The level of education the board members have, divided into five groups: vocational educa- } \\
\text { tion, secondary education, higher education, doctor's degree and professor's degree. }\end{array}$ \\
\hline age & $\begin{array}{l}\text { The division of board members according to age into five groups: less than } 35,35-44 \text {, } \\
45-54,55-64 \text { and older ones. }\end{array}$ \\
\hline gender & The division of board members according to gender into two groups: women and men. \\
\hline
\end{tabular}

Source: Authors' own preparation. 
Table 3.

Descriptive statistics

\begin{tabular}{|c|c|c|c|c|c|c|c|}
\hline Specification & Mean & Standard deviation & Median & Minimum & Q1 & Q3 & Maximum \\
\hline \multicolumn{8}{|c|}{ Panel A: depend variables } \\
\hline FER & -0.1621 & 0.5952 & -0.0164 & -3.2360 & -0.2870 & 0.0967 & 0.9510 \\
\hline AFER & 0.3405 & 0.5135 & 0.1937 & 0.0011 & 0.0518 & 0.3814 & 3.2360 \\
\hline accurate & 0.3846 & 0.4889 & 0.0000 & 0.0000 & 0.0000 & 1.0000 & 1.0000 \\
\hline optimistic & 0.3750 & 0.4865 & 0.0000 & 0.0000 & 0.0000 & 1.0000 & 1.0000 \\
\hline pessimistic & 0.2404 & 0.4294 & 0.0000 & 0.0000 & 0.0000 & 0.0000 & 1.0000 \\
\hline \multicolumn{8}{|c|}{ Panel B: management board characteristics } \\
\hline edu_type & 0.3101 & 0.2407 & 0.4444 & 0.0000 & 0.0000 & 0.5000 & 0.6667 \\
\hline edu_lev & 0.0927 & 0.1817 & 0.0000 & 0.0000 & 0.0000 & 0.0000 & 0.5000 \\
\hline age & 0.3392 & 0.2431 & 0.4444 & 0.0000 & 0.0000 & 0.5000 & 0.7200 \\
\hline gender & 0.1228 & 0.1969 & 0.0000 & 0.0000 & 0.0000 & 0.3200 & 0.5000 \\
\hline size & 2.8269 & 1.0376 & 3.0000 & 1.0000 & 2.0000 & 3.0000 & 6.0000 \\
\hline ownership & 0.4904 & 0.4123 & 0.5009 & 0.0000 & 0.0287 & 0.9443 & 1.1491 \\
\hline \multicolumn{8}{|c|}{ Panel C: supervisory board characteristics } \\
\hline edu_type & 0.5461 & 0.1334 & 0.5600 & 0.0000 & 0.4800 & 0.6400 & 0.7400 \\
\hline edu_lev & 0.3117 & 0.2152 & 0.3200 & 0.0000 & 0.1350 & 0.4800 & 0.7200 \\
\hline age & 0.5732 & 0.1251 & 0.5657 & 0.0000 & 0.4800 & 0.6400 & 0.8000 \\
\hline gender & 0.2310 & 0.1887 & 0.3200 & 0.0000 & 0.0000 & 0.3200 & 0.5000 \\
\hline size & 5.2596 & 0.7758 & 5.0000 & 3.0000 & 5.0000 & 5.0000 & 10.0000 \\
\hline ownership & 0.3991 & 0.4073 & 0.2944 & 0.0000 & 0.0000 & 0.8626 & 1.1060 \\
\hline \multicolumn{8}{|c|}{ Panel D: control variables } \\
\hline horizon & 5.1221 & 0.7099 & 5.2908 & 3.2581 & 4.7137 & 5.6568 & 6.1883 \\
\hline assets & 10.7090 & 1.4677 & 10.7962 & 5.6768 & 9.8402 & 11.6624 & 14.3137 \\
\hline
\end{tabular}

Source: Authors' own preparation. 
Table 4.

Correlation matrix

\begin{tabular}{lrrrrrrrr}
\hline Variables & edu_type & \multicolumn{1}{c}{ edu_lev } & \multicolumn{1}{c}{ age } & \multicolumn{1}{c}{ gender } & \multicolumn{1}{c}{ size } & ownership & \multicolumn{1}{c}{ horizon } & assets \\
\hline \multirow{2}{*}{ edu_type } & 1.000 & 0.3135 & 0.5000 & 0.1949 & 0.3654 & -0.2052 & 0.1266 & 0.1173 \\
& & $(0.0012)$ & $(0.0000)$ & $(0.0474)$ & $(0.0001)$ & $(0.0366)$ & $(0.2002)$ & $(0.2357)$ \\
edu_lev & -0.0182 & 1.0000 & 0.1228 & 0.0259 & 0.1518 & 0.0022 & -0.0024 & -0.1260 \\
& $(0.8544)$ & & $(0.2143)$ & $(0.7942)$ & $(0.1239)$ & $(0.9824)$ & $(0.9810)$ & $(0.2024)$ \\
age & 0.0942 & 0.2045 & & 0.3507 & 0.4083 & -0.0726 & 0.0247 & 0.2768 \\
& $(0.3415)$ & $(0.0373)$ & 1.0000 & $(0.0003)$ & $(0.0000)$ & $(0.4638)$ & $(0.8037)$ & $(0.0045)$ \\
gender & 0.2633 & -0.1455 & 0.0109 & & 0.2128 & -0.0035 & 0.0542 & -0.0151 \\
& $(0.0069)$ & $(0.1406)$ & $(0.9127)$ & 1.0000 & $(0.0301)$ & $(0.9719)$ & $(0.5845)$ & $(0.8792)$ \\
size & 0.1192 & 0.0596 & 0.1435 & -0.0569 & & -0.0315 & -0.0247 & 0.3799 \\
& $(0.2280)$ & $(0.5479)$ & $(0.1462)$ & $(0.5665)$ & 1.0000 & $(0.7509)$ & $(0.8032)$ & $(0.0001)$ \\
ownership & 0.1878 & 0.1918 & -0.0185 & 0.3000 & -0.1729 & & -0.0153 & -0.0814 \\
& $(0.0562)$ & $(0.0511)$ & $(0.8524)$ & $(0.0020)$ & $(0.0792)$ & 1.0000 & $(0.8772)$ & $(0.4113)$ \\
horizon & 0.0138 & 0.0003 & -0.0879 & -0.0034 & -0.0895 & 0.0146 & 1.0000 & 0.1139 \\
& $(0.8896)$ & $(0.9977)$ & $(0.3750)$ & $(0.9730)$ & $(0.3662)$ & $(0.8828)$ & & $(0.2496)$ \\
assets & 0.1831 & 0.1329 & 0.3232 & 0.1179 & 0.3116 & 0.0455 & 0.1139 & 1.0000 \\
\hline
\end{tabular}

Note:

The numbers placed above the diagonal of the matrix represent the correlation coefficients for the management board and below for the supervisory board. The numbers in parentheses report p-value of each correlation coefficient.

Source: Authors' own preparation. 
Table 5 .

The results of OLS and Logit regression models: management board

\begin{tabular}{|c|c|c|c|c|c|}
\hline Variable & FER & AFER & accurate & optimistic & pessimistic \\
\hline \multirow{2}{*}{ C } & 0.4010 & -0.1722 & 3.2820 & -5.4124 & -2.0635 \\
\hline & $(0.7455)$ & $(-0.3852)$ & $(1.4617)$ & $\left(-2.1059^{* *}\right)$ & $(-0.7699)$ \\
\hline \multirow{2}{*}{ edu_type } & -0.0092 & -0.0114 & 1.0688 & -0.6662 & -0.3434 \\
\hline & $(-0.0326)$ & $(-0.0488)$ & $(0.8846)$ & $(-0.5542)$ & $(-0.2477)$ \\
\hline \multirow{2}{*}{ edu_lev } & -0.1039 & 0.1825 & -1.2614 & 0.5751 & 0.7327 \\
\hline & $(-0.3279)$ & $(0.6931)$ & $(-0.9175)$ & $(0.4049)$ & $(0.5199)$ \\
\hline \multirow{2}{*}{ age } & 0.5937 & -0.4203 & 0.5176 & -2.9382 & 2.6073 \\
\hline & $\left(2.1161^{* *}\right)$ & $\left(-1.8031^{*}\right)$ & $(0.4436)$ & $\left(-2.3624^{* *}\right)$ & $\left(1.8547^{*}\right)$ \\
\hline \multirow{2}{*}{ gender } & -0.9306 & 0.6931 & -2.4797 & 3.6230 & -1.4394 \\
\hline & $\left(-3.1535^{* * *}\right)$ & $\left(2.8266^{* * *}\right)$ & $\left(-1.8284^{*}\right)$ & $\left(2.6467^{* * *}\right)$ & $(-1.0226)$ \\
\hline \multirow{2}{*}{ size } & -0.0815 & 0.0477 & -0.0200 & -0.0086 & 0.0646 \\
\hline & $(-1.3133)$ & $(0.9242)$ & $(-0.0759)$ & $(-0.0317)$ & $(0.2241)$ \\
\hline \multirow{2}{*}{ ownership } & -0.0200 & -0.1827 & 0.5578 & 1.2052 & -1.9504 \\
\hline & $(-0.1505)$ & $(-1.6532)$ & $(0.9794)$ & $\left(1.9805^{* *}\right)$ & $\left(-2.8117^{* * *}\right)$ \\
\hline \multirow{2}{*}{ horizon } & -0.2456 & 0.2734 & -1.2210 & 1.2339 & 0.3683 \\
\hline & $\left(-3.1907^{* * *}\right)$ & $\left(4.2744^{* * *}\right)$ & $\left(-3.4626^{* * *}\right)$ & $\left(3.1183^{* * *}\right)$ & $(0.9238)$ \\
\hline \multirow{2}{*}{ assets } & 0.0804 & -0.0830 & 0.1971 & -0.1397 & -0.1049 \\
\hline & $\left(1.9230^{*}\right)$ & $\left(-2.3899^{* *}\right)$ & $(1.0675)$ & $(-0.7351)$ & $(-0.5673)$ \\
\hline adjusted R-squared & 0.1744 & 0.2343 & & & \\
\hline McFadden R-squared & & & 0.1440 & 0.2105 & 0.1348 \\
\hline F-statistic & 3.7195 & 4.9396 & & & \\
\hline probability (F-statistic) & 0.0008 & 0.0000 & & & \\
\hline LR statistic & & & 19.9560 & 28.9681 & 15.4636 \\
\hline probability (LR statistic) & & & 0.0105 & 0.0003 & 0.0507 \\
\hline method & OLS & OLS & logit & logit & logit \\
\hline$N$ & 104 & 104 & 104 & 104 & 104 \\
\hline
\end{tabular}

Note:

The numbers in parentheses represents the t-value of significance and *, ${ }^{* *}$, and ${ }^{* * *}$ represent statistical significance at the $10 \%, 5 \%$, and $1 \%$ levels.

Source: Authors' own preparation. 
Table 6.

The results of OLS and Logit regression models: supervisory board

\begin{tabular}{|c|c|c|c|c|c|}
\hline Variable & FER & AFER & accurate & optimistic & pessimistic \\
\hline \multirow{2}{*}{ C } & -0.4989 & 0.1869 & 4.5006 & 0.6589 & -5.8292 \\
\hline & $(-0.7737)$ & $(0.3478)$ & $(1.5595)$ & $(0.1850)$ & $\left(-1.9243^{* *}\right)$ \\
\hline \multirow{2}{*}{ edu_type } & -0.3912 & 0.4059 & -4.5463 & 4.0759 & 0.4330 \\
\hline & $(-0.9107)$ & (1.1338) & $\left(-2.3787^{* *}\right)$ & $\left(1.9977^{* *}\right)$ & $(0.2250)$ \\
\hline \multirow{2}{*}{ edu_lev } & 0.2188 & 0.0427 & -1.1688 & 0.0171 & 1.6919 \\
\hline & $(0.8143)$ & $(0.1907)$ & $(-0.9818)$ & $(0.0146)$ & $(1.3639)$ \\
\hline \multirow{2}{*}{ age } & 1.4228 & -1.1888 & 4.3331 & -4.0214 & 0.3578 \\
\hline & $\left(3.0509^{* * *}\right)$ & $\left(-3.0587^{* * *}\right)$ & $\left(1.8567^{*}\right)$ & $-\left(1.8986^{*}\right)$ & $(0.1673)$ \\
\hline \multirow{2}{*}{ gender } & 0.1788 & -0.2038 & 3.0858 & -2.1402 & -0.6824 \\
\hline & $(0.5674)$ & $(-0.7761)$ & $\left(2.0537^{* *}\right)$ & $(-1.5431)$ & $(-0.4892)$ \\
\hline \multirow{2}{*}{ size } & 0.0577 & 0.0020 & -0.2020 & -0.8962 & 0.5808 \\
\hline & $(0.7630)$ & $(0.0315)$ & $(-0.5994)$ & $(-1.5971)$ & $\left(1.7460^{*}\right)$ \\
\hline \multirow{2}{*}{ ownership } & 0.0042 & -0.0745 & -0.2741 & 0.6040 & -0.5341 \\
\hline & $(0.0287)$ & $(-0.6077)$ & $(-0.4230)$ & $(0.9579)$ & $(-0.8055)$ \\
\hline \multirow{2}{*}{ horizon } & -0.2132 & 0.2553 & -1.2806 & 1.0823 & 0.4198 \\
\hline & $\left(-2.7514^{* * *}\right)$ & $\left(3.9543^{* * *}\right)$ & $\left(-3.4374^{* * *}\right)$ & $\left(2.7516^{* * *}\right)$ & (1.0977) \\
\hline \multirow{2}{*}{ assets } & 0.0385 & -0.0599 & 0.2124 & -0.1771 & -0.1157 \\
\hline & $(0.9199)$ & $\left(-1.7182^{*}\right)$ & (1.1194) & $(-0.9433)$ & $(-0.5838)$ \\
\hline adjusted R-squared & 0.1623 & 0.2184 & & & \\
\hline McFadden R-squared & & & 0.2057 & 0.1936 & 0.0685 \\
\hline F-statistic & 3.4952 & 4.5973 & & & \\
\hline probability (F-statistic) & 0.0014 & 0.0001 & & & \\
\hline LR statistic & & & 28.5129 & 26.6381 & 7.8628 \\
\hline probability (LR statistic) & & & 0.0004 & 0.0008 & 0.4470 \\
\hline method & OLS & OLS & logit & logit & logit \\
\hline$N$ & 104 & 104 & 104 & 104 & 104 \\
\hline
\end{tabular}

Note:

The numbers in parentheses represents the t-value of significance and *, ${ }^{* *}$, and ${ }^{* * *}$ represent statistical significance at the $10 \%, 5 \%$, and $1 \%$ levels, respectively.

Source: Authors' own preparation. 
Chart 1.

Management board structure

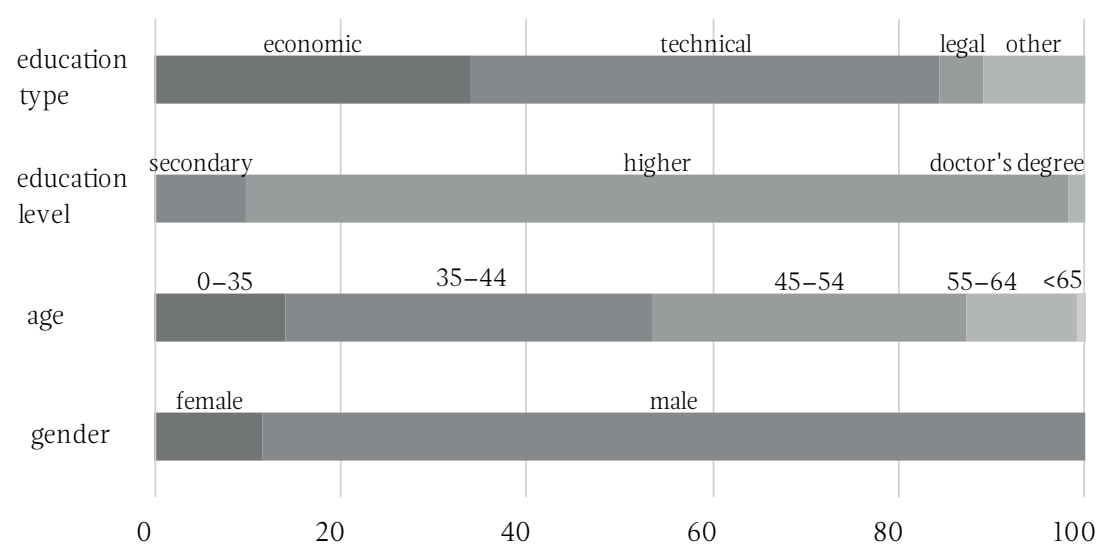

Source: Authors' own preparation.

\section{Chart 2.}

\section{Supervisory board structure}

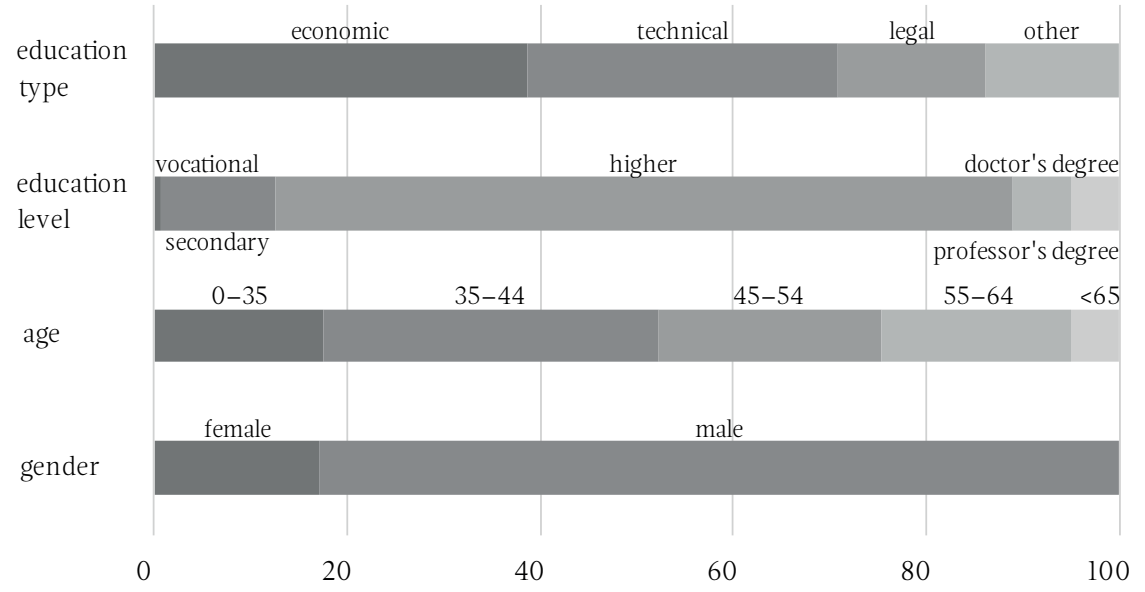

Source: Authors' own preparation. 
